\title{
Changes in chemistry, color, dimensional stability and fungal resistance of Pinus radiata D. Don wood with oil heat-treatment
}

\author{
Manoj Kumar Dubey ${ }^{1}$, Shusheng Pang ${ }^{1, *}$ and John \\ Walker $^{2}$ \\ ${ }^{1}$ Department of Chemical and Process Engineering, \\ University of Canterbury, Private Bag 4800, Christchurch, \\ New Zealand \\ ${ }^{2}$ School of Forestry, University of Canterbury, Private Bag \\ 4800, Christchurch, New Zealand \\ * Corresponding author. \\ Department of Chemical and Process Engineering, University of \\ Canterbury, Private Bag 4800, Christchurch, New Zealand \\ Phone: +64-3-3642538 \\ Fax: +64-3-3642063 \\ E-mail: shusheng.pang@ canterbury.ac.nz
}

\begin{abstract}
Pinus radiata wood specimens were heat-treated at $160-210^{\circ} \mathrm{C}$ in linseed oil and the effects of treatment on chemical composition, color, dimensional stability, and fungal resistance were examined. The degradation of hemicelluloses was the most remarkable feature, which is the principal reason for alterations in wood properties. Removal or migration of extractives, oil uptake and the accumulation of oil on the wood surface were observed. The color of heattreated wood became more uniform and darker, and its dimensional stability (i.e., anti-swelling efficiency) and fungal resistance were improved by up to $60 \%$ and $36 \%$, respectively. The viscosity of the oil after treatment was elevated with the treatment temperature and was higher in comparison to heated oil without wood present.
\end{abstract}

Keywords: chemical change; $\mathrm{CIEL}^{*} a^{*} b^{*}$ system; color variation; dimensional stability; heat treatment; linseed oil; weight percentage change (WPC).

\section{Introduction}

Wood from plantation forests is increasingly important due to depletion of tropical forests and desire to restrict utilization of natural forests. Pinus radiata D. Don is one of the most important fast grown plantation species in the Oceania, South America and South Africa. Worldwide, the plantation area of $P$. radiata is about $4.3 \times 10^{6}$ ha (Lungo et al. 2006), which contributes $1.1 \%$ of the global and $8.8 \%$ of the AsiaPacific trade in forest products (FAO 2005). $P$. radiata is considered to be the backbone of New Zealand forestry with about $1.6 \times 10^{6}$ ha of plantation area. The annual sustainable harvest of $P$. radiata in New Zealand is $18 \times 10^{6} \mathrm{~m}^{3}$ and is predicted to increase to $24 \times 10^{6} \mathrm{~m}^{3}$ by 2015 and $35 \times 10^{6} \mathrm{~m}^{3}$ during 2015-2025 (MAF 2010). Its potential as wood supplier is large across the globe.

The $P$. radiata wood has a cream white color, clear wood growth ring pattern, and moderate mechanical properties. Its stability and durability are regarded as inferior to other commercial species, such as ponderosa pine and Douglas-fir (Bamber and Burley 1983; Dickson and Walker 1997; Maclaren 2002). Thus it has a relatively weak position in the global markets in comparison with the species as mentioned above (Walker 2006; Wang et al. 2008).

Wood quality can be improved by heat treatment with temperatures usually below $260^{\circ} \mathrm{C}$ (Hill 2006). Heat treatment of wood belongs to the most important innovations of the last decade and such products are since a couple of years commercially available. Changes caused by heat treatment in chemical composition and physical properties (with dimensional stability in focus) were intensely investigated (Repellin and Guyonnet 2005; Esteves et al. 2008a; Tuong and Li 2011). Even the dimensional stability of MDF panels can be improved when the fibers are heat-treated (Garcia et al. 2006). The surface composition was investigated by modern analytical instruments, such as XPS and ToF-SIMS by Bryne et al. (2010). Parallels between natural ageing and heat treatment with focus on color changes were addressed by Matsuo et al. (2011). Color change of thermally modified wood was the topic of Gonzáles-Pena and Hale (2009a,b). Rapp et al. (2006) revealed interesting interrelationships between the severity of heat treatments and mechanical properties in impact milling experiments. Brischke et al. (2007) reported on the interrelationship between heat treatment intensities and color data of wood. The improved wettability of heat-treated wood is well known (Pétrissans et al. 2003; Hakkou et al. 2005) and Wolkenhauer et al. (2008) investigated recently the surface free energy of heat treated beech wood. It is obvious from studies based on hydrogen-deuterium exchange and ${ }^{2} \mathrm{H}$ NMR spectroscopy that the number of accessible $\mathrm{OH}$ groups in heat treated wood is decreased (Phuong et al. 2007). The wood water relationship of heat treated wood was illuminated by Almeida et al. (2009).

Treatment in hot vegetable oils with boiling points higher than $260^{\circ} \mathrm{C}$ is one of the alternatives to heating in dry state or in steam (Sailer et al. 2000a,b; Welzbacher and Rapp 2002; Wang and Cooper 2005); for oil properties see Gunstone (2002). The advantages of heat treatment in oil are the absence of oxygen, uniform and fast heat transfer rate to wood, and surface protection by the absorbed oil (Sailer et al. 2000a,b). Stamm et al. (1946) were the pioneers of this type of treatment. The authors treated wood in a bath of 
molten metal between $160^{\circ} \mathrm{C}$ and $320^{\circ} \mathrm{C}$ and called the dimensionally stabilized wood Staybwood. The degree of reduction in hygroscopicity and anti-swelling efficiency (ASE) almost doubled with every $10^{\circ} \mathrm{C}$ temperature rise. In the last decade, the Menz Holz Process was developed in Germany, in which wood is heat-treated at $180-220^{\circ} \mathrm{C}$ in refined rapeseed and linseed oils in a closed process vessel (Sailer et al. 2000a,b). Welzbacher and Rapp (2002) examined the biological properties of the heat-treated wood originating from four different European industrial heat-treatment plants. The decay resistance of wood heattreated in oil was better than that heat-treated in air under identical treatment conditions. The improvement was attributed to exclusion of oxygen. Of course, the results of heattreatment are also dependent on the wood species (Hill 2006) and the type of heating oil (Wang and Cooper 2005). Tjeerdsma et al. (2005) examined the performance of maleinized linseed oil, while Wang and Cooper (2005) focused on non-drying oils, such as palm oil, soy oil and slack wax. The latter was most suitable in terms of dimensional stability improvement. Manalo and Acda (2009) treated three bamboo species at $160-200^{\circ} \mathrm{C}$ in coconut oil. The principal reason for property changes in wood heat-treated in gaseous atmosphere is due to changes in chemical composition (Tjeerdsma et al. 1998b; Tjeerdsma and Militz 2005; Windeisen et al. 2007). For oil heat-treated wood, oil uptake also contributes to quality improvement.

There are no reports on oil heat treatment for $P$. radiata, thus the present study intends to close this gap. The linseed oil treated wood will be investigated for changes in chemical composition, color and weight changes, dimensional stability, and fungal resistance. The viscosity change of the oil during heating both with and without wood specimens in it will also be addressed.

\section{Materials and methods}

\section{Specimen preparation}

Clear Pinus radiata D. Don specimens, $300 \times 90 \times 20 \mathrm{~mm}^{3}$ $(\mathrm{L} \times \mathrm{T} \times \mathrm{R})$, were cut from kiln dried, flatsawn sapwood boards. Eight specimens were prepared for each treatment. Specimens were oven-dried for $48 \mathrm{~h}$ at $102^{\circ} \mathrm{C}$, cooled over silica gel desiccator before being placed in conditioning chamber at $65 \%$ relative humidity $(\mathrm{RH})$ and $20^{\circ} \mathrm{C}$ for two to three weeks to attain equilibrium.

\section{Heat treatment}

Conditioned specimens at $10-12 \%$ moisture content (MC) were immersed in a preheated oil bath at set temperatures of $160^{\circ} \mathrm{C}$, $180^{\circ} \mathrm{C}$, or $210^{\circ} \mathrm{C}$ for $1 \mathrm{~h}, 3 \mathrm{~h}$, or $6 \mathrm{~h}$ in commercial grade raw linseed oil. The oil bath was covered but no external pressure was applied. The oil was continuously recirculated, maintaining the operating temperature within one degree of the set point. After treatment, the lid of the oil bath was removed and the oil was left to cool for the desired period of time; then the oil was drained off and the specimens removed. Treated specimens were wiped, oven-dried at $102^{\circ} \mathrm{C}$ for $24 \mathrm{~h}$, then cooled down over silica gel in a desiccator and weighed. Finally, the specimens were placed in a conditioning chamber at $65 \% \mathrm{RH}$ and $20^{\circ} \mathrm{C}$ for two to three weeks until equilibrium was attained.

\section{Properties measurements}

Wet chemical analysis The wood samples were ground to a sieve size of $25-40$ mesh $(0.25-0.4 \mathrm{~mm})$. Extraction by ethanolbenzene $(1: 2)$ and hot water were conducted according to TAPPI Standard (TAPPI-T264 1995). Acid insoluble lignin (Klason lignin) was determined from extracted wood according to TAPPI-T222 (1988). Determination of holocellulose: according to the sodium hypochlorite method (Rowell 2005); $\alpha$-cellulose in holocellulose: according to $\mathrm{NaOH}$ method (Rowell 2005). The hemicellulose content was calculated by subtracting the $\alpha$-cellulose content from that of holocellulose. All the reported percentages of chemical constituents in this paper are averaged values from three replicates to the nearest of $\pm 0.1 \%$.

FTIR spectrometry Perkin Elmer System 2000 FTIR spectrometer. The wood samples were powdered and screened though a 12 mesh sieve $(0.12 \mathrm{~mm})$, extracted according to TAPPI-T264 (1995), and vacuum-dried at $70 \pm 3^{\circ} \mathrm{C}$ for $48 \mathrm{~h}$. The usual $\mathrm{KBr}$ pellet technique was applied for accumulation of 64 scans at the resolution of $4 \mathrm{~cm}^{-1}$. The FTIR spectra were baseline-corrected and normalized at the absorption band of maximum and minimum spectra according to the procedure given in the manual of Essential FTIR analysis software.

Color Measured by the CIE $L^{*} a * b *$ system (St-Onge et al. 2005; Esteves et al. 2008b; Ahajji et al. 2009). Instrument: Minolta spectrophotometer (model cm2500d). Diameter of measured circle: $10 \mathrm{~mm}$. Light source: Standard Illuminant D 65 which represents the average daylight including UV region and $10^{\circ}$ standard observer. The specimens were stabilized at $20 \pm 2^{\circ} \mathrm{C}$ and $65 \% \mathrm{RH}$ before the measurements. For each specimen, six measurement points were marked and the measurements were taken both before and after the treatment. Color comparison was also made between two opposite flat surfaces and between core and surface of each specimen.

Weight percentage change (WPC) WPC of the specimens after treatments are presented on the oven-dry basis. Oven-drying: $102 \pm 2^{\circ} \mathrm{C}$ for $48 \mathrm{~h}$; cooling: over a silica gel in desiccators; accuracy of weighting: $\pm 0.001 \mathrm{~g}$. WPC $(\%)=100 \times\left(\mathrm{W}_{\mathrm{a}}-\mathrm{W}_{\mathrm{b}}\right) / \mathrm{W}_{\mathrm{b}}$, in which, $\mathrm{W}_{\mathrm{b}}$ is the oven-dry weight before treatment $(\mathrm{g})$, and $\mathrm{W}_{\mathrm{a}}$ is the oven-dry weight after the treatment $(\mathrm{g})$.

Dimensional stability Measured by exposing the treated and untreated samples in three environments: 1 . in water bath at $20 \pm 2^{\circ} \mathrm{C}, 2$. in high humidity condition $\left(85 \pm 5 \% \mathrm{RH}, 20 \pm 2^{\circ} \mathrm{C}\right)$, and 3. with three cycles of dry-freeze-wet (DFW) conditions. Each DFW cycle consisted of three days of dry condition in an oven at $35 \pm 2{ }^{\circ} \mathrm{C}$ followed by a day of freezing at $-20^{\circ} \mathrm{C}$ and three days of water immersion at $20 \pm 2^{\circ} \mathrm{C}$. In the environment tests of one and two, the specimens were weighed and measured in L (length), T (width) and $\mathrm{R}$ (thickness) directions after different intervals until they reached equilibrium. Results were calculated on weight and dimensional changes against over-dry state. In the DFW cycle test, the weight and dimensions of the specimens were measured to the nearest $0.01 \mathrm{~mm}$ and $0.001 \mathrm{~g}$ at the end of three cycles, totally after 21 days. ASE $(\%)=100 \times\left(S_{c}-S_{t}\right) / S_{c}\left(\right.$ Stamm 1964), where $S_{t}$ is the volumetric or dimensional swelling ratio of treated wood compared to its oven-dry volume or dimension, and $\mathrm{S}_{\mathrm{c}}$ is the corresponding ratio of untreated wood. $\mathrm{S}_{\mathrm{c}}$ or $\mathrm{S}_{\mathrm{t}}(\%)=100 \times\left(\mathrm{X}_{2}-\mathrm{X}_{1}\right) / \mathrm{X}_{1}$, in which 
Table 1 Chemical composition of untreated and heat-treated wood. Average values are the mean of three replicates. Standard deviations are in parentheses. Values followed by a different letter within a column are statistically different at $\mathrm{P}=0.05$ (ANOVA Single Factor and t-test).

\begin{tabular}{lcccc}
\hline & $\begin{array}{c}\text { Holocel- } \\
\text { Acid insol. } \\
\text { Treatment } \\
\text { residue (\%) }\end{array}$ & $\begin{array}{c}\text { lulose }(\mathrm{A}) \\
(\%)\end{array}$ & $\begin{array}{c}\alpha \text {-Cellulose } \\
(\mathrm{B})(\%)\end{array}$ & $\begin{array}{c}\text { Hemicellu- } \\
\text { loses (A-B) } \\
(\%)\end{array}$ \\
\hline Control & $26.0^{\mathrm{X}}(0.5)$ & $72.2^{\mathrm{X}}(1.9)$ & $42.0^{\mathrm{X}}(1.3)$ & 30.2 \\
$160^{\circ} \mathrm{C}-3 \mathrm{~h}$ & $25.5^{\mathrm{X}}(1.6)$ & $70.2^{\mathrm{X}}(1.5)$ & $43.1^{\mathrm{X}}(1.0)$ & 27.1 \\
$180^{\circ} \mathrm{C}-3 \mathrm{~h}$ & $36.0^{\mathrm{Y}}(1.8)$ & $61.3^{\mathrm{Y}}(0.9)$ & $41.6^{\mathrm{X}}(0.9)$ & 19.7 \\
$210^{\circ} \mathrm{C}-3 \mathrm{~h}$ & $48.4^{\mathrm{Z}}(1.8)$ & $49.4^{\mathrm{Z}}(0.5)$ & $39.8^{\mathrm{Y}}(0.9)$ & 9.5 \\
\hline
\end{tabular}

$\mathrm{X}_{1}$ is the oven-dry volume $\left(\mathrm{cm}^{3}\right)$ or dimension $(\mathrm{cm})$ before test and $\mathrm{X}_{2}$ is the volume $\left(\mathrm{cm}^{3}\right)$ or dimension $(\mathrm{cm})$ of the specimens after test.

The biological efficacy of the treated wood Evaluated by the Wood Mycology Laboratory at Scion, Rotorua, New Zealand, based on the agar block decay test following the standard "Sutter jar" method (Sutter 1978). This method is similar to that of European Standard EN-113 and British Standard BS 6009:1982 (Callahan and Chittenden 2009). However, it differs in exposure time to the decay organism, and in the present study, plastic Petri-dish containers were used instead of glass Kolle flasks (Stahlhut et al. 2008). Eight replicates of treated and untreated specimens, $35 \times 20 \times 7 \mathrm{~mm}^{3}$ $(\mathrm{T} \times \mathrm{R} \times \mathrm{L})$, were tested. The specimens were first leached for two weeks and air-dried for several days in the laboratory followed by oven-drying at $102 \pm 2^{\circ} \mathrm{C}$ for $18 \mathrm{~h}$. After this, the specimens were cooled down in silica gel desiccators and weighed. Then the specimens were sterilized by ethylene oxide gas. Finally, the specimens were placed into prepared Sutter agar containers. Incubation was at $26^{\circ} \mathrm{C}$ and $75 \% \mathrm{RH}$ for six weeks. The fungus used was Oilgoporus placenta, a common brown rot fungus found in leaky buildings in New Zealand (Stahlhut et al. 2008). After incubation, specimens were cleaned, oven-dried and weighed. The percentage weight losses (WL) of the specimens were calculated from the oven-dry weight of the specimens before the incubation $\left(\mathrm{M}_{\mathrm{b}}\right)$ and after the incubation $\left(\mathrm{M}_{\mathrm{a}}\right)$ according to the equation: WL $(\%)=100 \times$ $\left(\mathrm{M}_{\mathrm{b}}-\mathrm{M}_{\mathrm{a}}\right) / \mathrm{M}_{\mathrm{b}}$.

The oil viscosities Oil viscosities of fresh unheated linseed oil, and linseed oil heated at $160^{\circ} \mathrm{C}, 180^{\circ} \mathrm{C}$ and $210^{\circ} \mathrm{C}$ for $3 \mathrm{~h}$ with and without wood specimens in the oil were measured in a Haake viscometer with MV1 sensor at a shear rate of $1000 \mathrm{~s}^{-1}$ and temperature of $20.2 \pm 0.1^{\circ} \mathrm{C}$. The mean of 10 replicates was calculated.

\section{Results and discussion}

\section{Chemical analysis}

As demonstrated in Table 1, no significant changes in chemical constituents were found for the $160^{\circ} \mathrm{C}$ treatment, but the overall holocellulose content decreased by $15 \%$ and $32 \%$, respectively, at $180^{\circ} \mathrm{C}$ and $210^{\circ} \mathrm{C}$. The most significant change was for hemicellulose content, which decreased by approximately $35 \%$ and $69 \%$ at treatment temperatures of $180^{\circ} \mathrm{C}$ and $210^{\circ} \mathrm{C}$, respectively. This finding is in agreement with that of Mazella et al. (2004), who found a rapid hemicelluloses degradation at temperatures above $200^{\circ} \mathrm{C}$ during heat treatment in air. Hemicelluloses have low thermal stability (Fengel and Wegener 1984; Windeisen et al. 2007). Especially, their acetyl groups are split off in the form of acetic acid (Tjeerdsma et al. 1998a).

The $\alpha$-cellulose content diminished only slightly at $210^{\circ} \mathrm{C}$ (by 5\%) due to its crystalline structure (Fengel and Wegener 1984). The accessibility of glucosidic bonds in cellulose is also restricted compared to that of the hemicelluloses (Boonstra and Tjeerdsma 2006). Hill (2006) reported that cellulose degradation begins at $210-220^{\circ} \mathrm{C}$ and degradation accelerated above $270^{\circ} \mathrm{C}$ when levoglucosan and other break-down products are formed. Kim et al. (2001) also noted that severe degradation of the crystalline region occurs in a range of $300-340^{\circ} \mathrm{C}$.

Lignin is considered to be the most thermal stable wood constituent. At temperatures up to $600^{\circ} \mathrm{C}$, mass losses (ML) of hemicelluloses amount to over $95 \%$, and those of cellulose to more than $80 \%$, whereas ML of lignin does not exceed 60\% (Bartkowiak and Zakrzewski 2004). Significant lignin degradation occurs only at a temperature above $280^{\circ} \mathrm{C}$ (Akgül et al. 2007). The relative proportion of lignin in wood remained unchanged for wood treated at $160^{\circ} \mathrm{C}$ but increased at $180^{\circ} \mathrm{C}$ and $210^{\circ} \mathrm{C}$. The apparent increase in lignin content is partly due to the loss of holocellulose. Moreover, some of the thermally degraded carbohydrates may be incorporated within the lignin during the Klason lignin determination. This can lead to a falsely high estimation of lignin content (Zaman et al. 2000; Yildiz et al. 2006). Condensation reactions of lignin at temperatures higher than $200^{\circ} \mathrm{C}$ may also contribute to the changes in lignin content (Tjeerdsma and Militz 2005).

FTIR spectral data help to interpret the complex changes in wood upon heat treatment (Pandey 1999; Tjeerdsma and Militz 2005; Windeisen et al. 2007). The IR bands that showed important alterations are 1738, 1650, 1510, 1430, $1374,1267,1165,1113,1060$ and $1030 \mathrm{~cm}^{-1}$, but the general aspects of the spectra are very similar (results not shown). The $1738 \mathrm{~cm}^{-1}$ band is remarkably reduced after heat-treatment, which can be interpreted as hemicellulose degradation. The decline and shift of the $1650 \mathrm{~cm}^{-1}$ band reflects the decrease in absorbed water with increasing treatment temperature. At $210^{\circ} \mathrm{C}$ treatment the $1510 \mathrm{~cm}^{-1}$ band (lignin, aromatic ring) increased slightly, indicating the degradation of hemicelluloses and the relative increment of the lignin content. Based on the literature, it can be assumed that crosslinking density within the lignin network is increased at higher temperatures (Tjeerdsma et al. 1998a; Wikberg and Liisa Maunu 2004; Windeisen et al. 2007). The bands at $1060 \mathrm{~cm}^{-1}$ and $1030 \mathrm{~cm}^{-1}$ corresponding to $\mathrm{C}-\mathrm{O}$ stretching in cellulose and hemicelluloses decreased after the treatments which indicate depolymerization of polysaccharides.

\section{Weight and color changes of the treated wood}

Figure 1 shows the effect of treatment temperature and time on the mean weight percentage change (WPC) of the treated specimens. In general, the specimens gained a certain 


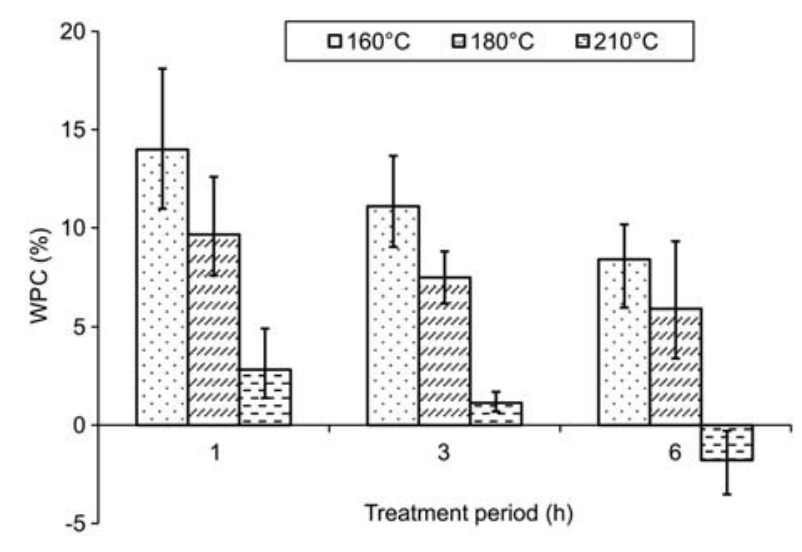

Figure 1 Weight percentage change (WPC, \%) of heat-treated Pinus radiata wood in oil for different treatment temperatures and treatment durations (number of specimens $n=8$ ).

amount of weight due to the oil uptake during the treatment, but the gain in specimen weight decreased with the increase in treatment temperature and treatment time. For $3 \mathrm{~h}$ treatments, the WPC values at $160^{\circ} \mathrm{C}, 180^{\circ} \mathrm{C}$, and $210^{\circ} \mathrm{C}$ were approximately $11 \%, 7.5 \%$ and $1 \%$, respectively. At a given treatment temperature, the WPC values were the greatest for $1 \mathrm{~h}$ treatments and the least for $6 \mathrm{~h}$ treatments. In fact, the specimens treated at $210^{\circ} \mathrm{C}$ for $6 \mathrm{~h}$ lost $1.8 \%$ weight due to the wood degradation.

The heat-treatment also affected the wood color, as expected, with the wood turning darker, but the wood color became more uniform on the exposed surfaces. The color of the wood treated at $160^{\circ} \mathrm{C}, 180^{\circ} \mathrm{C}$, and $210^{\circ} \mathrm{C}$ for $3 \mathrm{~h}$ was, respectively, yellowish brown, reddish-brown and dark-chocolate. No surface cracks, warp or twist were observed in the treated wood. The surface appeared shiny near the rays which may be due to a high uptake of oil by parenchyma cells compared to other wood tissues. The color change was similar on two flat faces of the specimens (Table 2) but the two faces became identical in color after treatment at high temperatures. When the wood was treated at $180^{\circ} \mathrm{C}$ and $210^{\circ} \mathrm{C}$, the total color difference $\left(\Delta E^{*}\right)$ and the brightness variation $\left(\Delta L^{*}\right)$ between the two surfaces was less than 1.5 units although the wood surfaces became darker. The human eye can distinguish color change only if $\Delta L^{*}$ is more than 3 units (Phelps et al. 1994) or the value of $\Delta E^{*}$ is $>2$ (Sundqvist 2002).

Color difference between core and surface for the treated specimens was found to be significant (Table 2, lower part). This difference, both for $\Delta E^{*}$ and for $\Delta L^{*}$, was reduced with increasing treatment temperature.

\section{Dimensional stability}

Table 3 presents the results of volumetric swelling percentage $(S)$ and anti swelling efficiency (ASE) of the treated wood as affected by treatment temperature (Table 3, upper part) and treatment duration (Table 3, lower part). Under all of the three test environments, the volumetric swelling of the treated wood decreased substantially compared to the untreated wood. The highest ASE of 53-60\% was found in specimens treated at $210^{\circ} \mathrm{C}$ whereas the ASE was less for specimens treated at $160^{\circ} \mathrm{C}(31-38 \%)$ and at $180^{\circ} \mathrm{C}(37-39 \%)$. At a given temperature, the ASE values were the least for the shortest treatment time $(1 \mathrm{~h})$. However, no significant difference was observed between specimens treated for $3 \mathrm{~h}$ and those for $6 \mathrm{~h}$.

The dimensional stability in $\mathrm{T}$ (width) and $\mathrm{R}$ (thickness) directions in the water immersion test are shown in Table 4 in which the ASE in T direction was greater than in R direction for all treatment temperatures. The values of ASE at $160^{\circ} \mathrm{C}$ in $\mathrm{T}$ and $\mathrm{R}$ directions were $19 \%$ and $13 \%$, respectively, while the corresponding values for wood treated as at $210^{\circ} \mathrm{C}$ were $42 \%$ and $40 \%$. This implies that wood becomes more stable and less anisotropic after treatments at high temperatures.

Table $2 \mathrm{CIE} L * a * b *$ values and color differences between the two flat surfaces no. 1 and 2 of treated and untreated specimens, and between surface and core of treated specimens.

\begin{tabular}{|c|c|c|c|c|c|c|c|c|}
\hline \multirow[b]{2}{*}{ Treatment } & \multirow{2}{*}{$\begin{array}{l}\text { Surface } \\
\text { or core }\end{array}$} & \multicolumn{3}{|c|}{ Color in CIE $L^{*} a^{*} b^{*}$ system } & \multicolumn{4}{|c|}{ Color difference } \\
\hline & & $L^{*}$ & $a^{*}$ & $b^{*}$ & $\Delta L^{*}$ & $\Delta a^{*}$ & $\Delta b^{*}$ & $\Delta E$ \\
\hline \multirow[t]{2}{*}{ Untreated } & Surf.1 & 68.1 & 11.51 & 33.8 & & & & \\
\hline & Surf. 2 & 64.3 & 12.2 & 31.8 & 3.8 & -0.8 & 2 & 4.3 \\
\hline \multirow[t]{2}{*}{$160^{\circ} \mathrm{C}-3 \mathrm{~h}$} & Surf. 1 & 65.9 & 12.3 & 38.2 & & & & \\
\hline & Surf. 2 & 62.5 & 13.2 & 37 & -3.3 & 0.9 & -1.2 & 3.6 \\
\hline \multirow[t]{2}{*}{$180^{\circ} \mathrm{C}-3 \mathrm{~h}$} & Surf. 1 & 61.2 & 13.7 & 36.8 & & & & \\
\hline & Surf. 2 & 59.8 & 14.1 & 36.6 & -1.4 & 0.4 & -0.3 & 1.5 \\
\hline \multirow[t]{2}{*}{$210^{\circ} \mathrm{C}-3 \mathrm{~h}$} & Surf. 1 & 47.1 & 13.8 & 26.3 & & & & \\
\hline & Surf. 2 & 46.1 & 13.3 & 25.6 & -0.9 & -0.5 & -0.7 & 1.2 \\
\hline \multirow[t]{2}{*}{$160^{\circ} \mathrm{C}-3 \mathrm{~h}$} & Surf. & 55 & 13.4 & 31.8 & & & & \\
\hline & Core & 70 & 7.3 & 27.5 & 15 & -6.1 & -4.2 & 16.7 \\
\hline \multirow[t]{2}{*}{$180^{\circ} \mathrm{C}-3 \mathrm{~h}$} & Surf. & 61.2 & 12 & 33.5 & & & & \\
\hline & Core & 74.7 & 6.9 & 27 & 13.6 & -5.1 & -6.6 & 15.9 \\
\hline \multirow[t]{2}{*}{$210^{\circ} \mathrm{C}-3 \mathrm{~h}$} & Surf. & 36.9 & 11.3 & 15.9 & & & & \\
\hline & Core & 47.3 & 11.8 & 26.7 & 10.4 & 0.6 & 10.8 & 15 \\
\hline
\end{tabular}


Table 3 Volumetric swelling percentage (S) and anti-swelling efficiency (ASE) of untreated and heattreated wood at different treatment temperatures (upper part) and at different treatment times (lower part). Average values are the mean of seven replicates. Standard deviations are given in parentheses. Values followed by a different letter within a column are statistically different at $\mathrm{P}=0.05$ (ANOVA Single Factor and t-test).

\begin{tabular}{|c|c|c|c|c|c|c|}
\hline & \multicolumn{2}{|c|}{ Water bath test } & \multicolumn{2}{|c|}{ High humidity test } & \multicolumn{2}{|c|}{ DFW cycle test } \\
\hline & $\mathrm{S}(\%)$ & $\operatorname{ASE}(\%)$ & $\mathrm{S}(\%)$ & $\operatorname{ASE}(\%)$ & $\mathrm{S}(\%)$ & $\operatorname{ASE}(\%)$ \\
\hline Control & $13.5^{\mathrm{x}}(1.6)$ & & $8.8^{\mathrm{X}}(1)$ & & $12.8^{\mathrm{X}}(2.3)$ & \\
\hline $160^{\circ} \mathrm{C}-3 \mathrm{~h}$ & $8.9^{\mathrm{Y}}(1.1)$ & 33.9 & $6.0^{\mathrm{Y}}(0.7)$ & 31.7 & $8.0^{\mathrm{Y}}(1.6)$ & 37.8 \\
\hline $180^{\circ} \mathrm{C}-3 \mathrm{~h}$ & $8.2^{\mathrm{Y}}(0.3)$ & 39.1 & $5.4^{\mathrm{Y}}(0.4)$ & 38.7 & $8.0^{\mathrm{Y}}(1.2)$ & 37.5 \\
\hline $210^{\circ} \mathrm{C}-3 \mathrm{~h}$ & $6.2^{\mathrm{Z}}(0.2)$ & 54.1 & $4.1^{\mathrm{Z}}(0.5)$ & 53.2 & $5.2^{\mathrm{Z}}(0.8)$ & 59.8 \\
\hline Control & $13.3^{\mathrm{x}}(0.8)$ & & $4.7^{\mathrm{x}}(1.6)$ & & $15.7^{\mathrm{x}}(2.2)$ & \\
\hline $180^{\circ} \mathrm{C}-1 \mathrm{~h}$ & $9.7^{\mathrm{Y}}(0.9)$ & 26.7 & $3.6^{\mathrm{X}}(1.3)$ & 22.4 & $8.8^{\mathrm{Y}}(1.2)$ & 43.9 \\
\hline $180^{\circ} \mathrm{C}-3 \mathrm{~h}$ & $8.2^{\mathrm{Z}}(0.4)$ & 38.2 & $2.7^{\mathrm{Y}}(0.8)$ & 42.9 & $7.7^{\mathrm{Z}}(1.3)$ & 50.8 \\
\hline $180^{\circ} \mathrm{C}-6 \mathrm{~h}$ & $8.2^{\mathrm{Z}}(0.7)$ & 38.4 & $2.5^{\mathrm{Y}}(0.9)$ & 45.9 & $7.5^{\mathrm{Z}}(91.3)$ & 52.2 \\
\hline
\end{tabular}

\section{Fungal resistance}

Figure 2 shows the results of WL from laboratory pure culture decay trials against brown rot fungus Oilgoporus placenta. This fungus has been reported to cause a greater WL in heat-treated wood compared to other wood decaying fungi, namely Coniophora putanea and Coriolus versicolor (Welzbacher and Rapp 2002). The results show that the resistance of wood against this fungus was improved with the oil heat-treatment. The WL in untreated wood was $19.2 \%$ which was reduced to $13.2-17.6 \%$ for treated wood. However, no

Table 4 Tangential swelling (TS), radial swelling (RS) percentages and anti-swelling efficiency (ASE) of heat-treated wood specimens. Standard deviations are given in parentheses. Values followed by a different letter within a column are statistically different at $\mathrm{P}=0.05$ (ANOVA Single Factor and t-test).

\begin{tabular}{lcccc}
\hline & $\begin{array}{c}\text { TS } \\
(\%)\end{array}$ & $\begin{array}{c}\text { ASE (TS) } \\
(\%)\end{array}$ & $\begin{array}{c}\text { RS } \\
(\%)\end{array}$ & $\begin{array}{c}\text { ASE (RS) } \\
(\%)\end{array}$ \\
\hline Control & $5.9^{\mathrm{X}}(0.3)$ & & $3.7^{\mathrm{X}}(0.1)$ & \\
$160^{\circ} \mathrm{C}-3 \mathrm{~h}$ & $4.9^{\mathrm{Y}}(0.5)$ & 18.6 & $3.1^{\mathrm{Y}}(0.5)$ & 12.7 \\
$180^{\circ} \mathrm{C}-3 \mathrm{~h}$ & $4.7^{\mathrm{Y}}(0.2)$ & 27.4 & $3.0^{\mathrm{Y}}(0.2)$ & 22.7 \\
$210^{\circ} \mathrm{C}-3 \mathrm{~h}$ & $3.4^{\mathrm{Z}}(0.2)$ & 41.9 & $2.3^{\mathrm{Z}}(0.1)$ & 39.9 \\
\hline
\end{tabular}

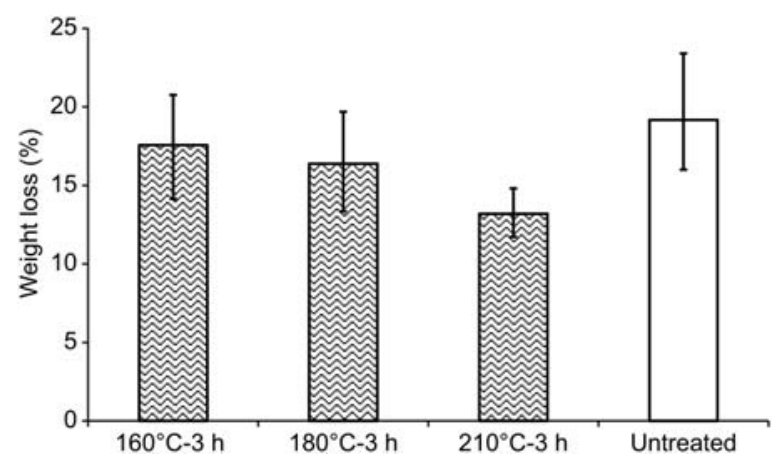

Figure 2 Mean percentage weight loss of heat-treated Pinus radiata wood in oil at $160^{\circ} \mathrm{C}, 180^{\circ} \mathrm{C}$, and $210^{\circ} \mathrm{C}$ for $3 \mathrm{~h}$ in a pure laboratory decay trial against Oilgoporus placenta (number of specimens $n=8$ ). significant difference $(\mathrm{P}<0.5$ ANOVA single factor $)$ in $\mathrm{WL}$ was found with the $160^{\circ} \mathrm{C}$ treatment. The specimens treated at $180^{\circ} \mathrm{C}$ and $210^{\circ} \mathrm{C}$ were improved moderately which matches the findings of others (Mazella et al. 2004; Paul et al. 2007). Based on the present study and studies of Kamdem et al. (2002) and Welzbacher and Rapp (2002), oil heat-treatment of $P$. radiata above $210^{\circ} \mathrm{C}$ could improve the durability of the species from non-resistant or perishable class to moderate resistant or resistant species depending on the fungus species and the treatment temperatures as defined in the Australian Standard and American Standard (AS5604 2003; ASTM-D2017 2005).

\section{Viscosity of the oil}

Figure 3 is a comparison of the viscosities of unheated and heated oils both with and without wood during heating. These observations are relevant for re-use of the oil for further heat-treatment cycles. As visible, the oil viscosity increased moderately with the heating temperature which is mainly attributed to evaporation of volatile components and polymerization of the linseed oil at high temperatures (Mabery 1923; Powers 1950). The viscosity of heated oils was slightly higher in the presence of wood than that without

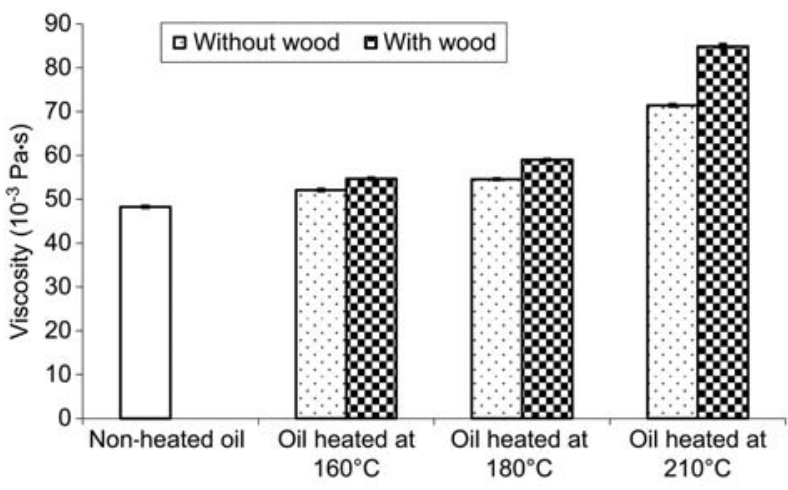

Figure 3 Mean viscosity (measured at $20.2 \pm 0.1^{\circ} \mathrm{C}$ ) of fresh oil and oil heated at $160^{\circ} \mathrm{C}, 180^{\circ} \mathrm{C}$, and $210^{\circ} \mathrm{C}$ for $3 \mathrm{~h}$ with and without wood. Values are the mean of 10 replicates. 
wood and this difference increased with the treatment temperature. This confirms that the release of wood extractives and wood degradation products contribute, to a certain extent, to the oil viscosity increment.

\section{Factors influencing properties of oil heat-treated wood}

The oil heat-treated P. radiata wood was darker in color, dimensionally more stable, and displayed a certain extent of improved fungal resistance. These changes can be due to: (a) change in wood chemistry at high temperatures; (b) the removal or migration of extractives and other compounds; and (c) oil uptake and the accumulation of oil on the wood surfaces.

Change in wood chemistry at high temperatures Oil heat-treatment resulted in changes in structure and proportions of the major chemical constituents of wood. The most significant changes occur in hemicelluloses as demonstrated by chemical analysis and FTIR spectroscopy. In a review by Rowell and Banks (1985), it is demonstrated that hygroscopicity of wood is a function of the content and structure of hemicelluloses, non-crystalline cellulose, surfaces of crystalline cellulose and, to a less degree, of lignin. Hemicelluloses play an essential role with this regard (Seborg et al. 1953; Hillis 1984; Evans 2003). Degradation of the hemicelluloses leads to a reduction of available free polar adsorption sites, mainly the hydroxyl groups are necessary for adsorption of water (Hillis 1984; Feist and Sell 1987). Denaturing (dehydroxylation) of polysaccharides hinder the fungi growth as they require adequate moisture in survival (Bowyer et al. 2003; Archer and Leebow 2006). Furthermore, at high temperatures above $210^{\circ} \mathrm{C}$, the hemicelluloses are degraded to less hygroscopic substances, such as furfural polymers which are also toxic to fungal growth (Stamm 1964; Kamdem et al. 2002). Boonstra et al. (2007) also reported that heat-treatment of wood can induce chemical transformation of other wood constituents essential for fungal infection, such as minerals, vitamins, and low molecular mass carbohydrates.

It is an established knowledge (Kollmann and Fengel 1965) that the hemicelluloses degradation contributes essentially to the increased dimensional stability of heat treated wood. As the hemicellulose degradation becomes severer at high temperatures, the dimensional stability and fungal resistance of specimens treated at $210^{\circ} \mathrm{C}$ are better than those treated at $160^{\circ} \mathrm{C}$ and $180^{\circ} \mathrm{C}$. The nature of color change is complex: all essential wood components including the extractives may contribute to it. The $\mathrm{pH}$ change (creation of acids) and heat promoted degradation and condensation reactions may contribute in various ways to the formation of chromophores (Bekhta and Niemz 2003).

Migration or removal of extractives and other compounds The heat-degraded compounds with low molecular weights tend to migrate towards the surfaces along with extractives (Theander et al. 1993; Sundqvist and Morén 2002). The oil viscosity increment confirms indirectly the removal of materials from wood (Mabery 1923; Powers
1950). But the color change is not restricted to the wood surface.

The color of the oil heat-treated specimens was found to be homogenous without any resin patches. In previous studies on thermally treated birch wood $\left(175-200^{\circ} \mathrm{C}\right.$ for $1-10 \mathrm{~h}$ in steam) non-homogenous distribution of color was observed (Johansson and Morén 2006). Obviously, during the heat-treatment in air or steam, migration of extractives towards the surface leads to the formation of unsightly resin spots in wood (Mayes and Oksanen 2002). The oil as a heating medium provides an oxygen-free environment and uniform heat transfer from oil to wood compared to air or steam as heating medium (Sailer et al. 2000a), thus the color is more uniform.

Oil uptake and the accumulation of oil on the wood surface From the results presented in Figure 1, it is visible that the greatest net weight gain (14\%) was for wood treated at $160^{\circ} \mathrm{C}$ for $1 \mathrm{~h}$, which can be attributed to the greatest oil uptake under this condition. However, the actual oil uptake at higher temperatures should be greater than the measured values considering the weight loss due to wood degradation and removal of extractives. The wood loss was more severe for wood treated at $210^{\circ} \mathrm{C}$ for $6 \mathrm{~h}$ and the net weight loss of wood treated under this condition was about $1.8 \%$.

Linseed oil is hydrophobic (ASTM-D234-82 1998; Chemwatch 2007) and non-swelling as its molecule size is too large to penetrate in the cell wall (Rosenqvist 2000; Olsson et al. 2001; Hill 2006). Thus, the absorbed oil in the treated wood remains in the cell lumens. On this basis, contribution of the absorbed oil to the wood dimensional stability is expected to be limited. Therefore, specimens treated at $160^{\circ} \mathrm{C}$ with the highest oil uptake exhibited more volumetric swelling (Table 3) and less fungal resistance (Figure 2) than specimens treated at $210^{\circ} \mathrm{C}$. Obviously, chemical changes at higher temperatures are more influential for dimensional stability and fungal resistance than the oil uptake alone. On the other hand, hydrophobic oils in the lumens block the water uptake of the walls and contribute indirectly to quality improvements (Wang and Cooper 2005). Furthermore, being a drying oil, the linseed oil forms a stable film on the outer and inner surfaces so that the barrier to water absorption is long-standing.

\section{Conclusions}

P. radiata wood was heat-treated in a linseed oil bath over a range of temperatures and times. Wet chemical analysis and FTIR analysis confirmed that the wood heat-treatment resulted in degradation of hemicelluloses (up to $70 \%$ ). The treated wood was less hygroscopic and more dimensionally stable. The anti swelling efficiency (ASE) of the treated wood was found to range from $31 \%$ to $60 \%$, depending on the treatment temperature and time. The ASE in the tangential direction was greater than in the radial direction; however, the differences between the two directions decreased with higher treatment temperatures. The resistance of the 
treated wood against the brown rot fungus Oilgoporus placenta was also improved moderately by up to $30 \%$ (at $210^{\circ} \mathrm{C}$ ). The degradation of hemicelluloses contributes largely to improvement in dimensional stability and fungal resistance of the treated wood. The color of the treated specimens became uniformly darker without patches. Oil heat-treatment of $P$. radiata wood can be an effective way to improve its dimensional stability and its color quality.

\section{Acknowledgements}

The authors wish to thank Ms. Diahanna O'Callahan of the Scion, Rotorua, New Zealand, for conducting the laboratory decay trials and Mahbubul Hassan of the AgResearch Ltd, Lincoln, New Zealand, for his help in the chemical analysis of the oil heat-treated wood. Postgraduate Scholarship from New Zealand Aid (NZAID) is acknowledged by the senior author.

\section{References}

Ahajji, A., Diouf, P., Aloui, F., Elbakali, I., Perrin, D., Merlin, A., George, B. (2009) Influence of heat treatment on antioxidant properties and colour stability of beech and spruce wood and their extractives. Wood Sci. Technol. 43:69-83.

Akgül, M., Gümüskaya, E., Korkut, S. (2007) Crystalline structure of heat-treated Scots pine [Pinus sylvestris L.] and Uludağ fir [Abies nordmanniana (Stev.) subsp. bornmuelleriana (Mattf.)] wood. Wood Sci. Technol. 41:281-289.

Almeida, G., Brito, J.O., Perré, P. (2009) Changes in wood-water relationship due to heat treatment assessed on micro-samples of three Eucalyptus species. Holzforschung 63:80-88.

American Society for Testing and Materials (1998) ASTM-D23482, Standard specification for raw linseed oil.

American Society for Testing and Materials (2005) ASTM-D2017, Standard test method of accelerated laboratory test of natural decay resistance of woods.

Archer, K., Leebow, S. (2006) Wood preservation. In: Primary Wood Processing: Principles and Practice. Ed. Walker J.C.F. Springer, Dordrecht, The Netherlands, pp. 297-338.

Australian Standard (2003) AS5604, Timber-Natural durability ratings.

Bamber, R.K., Burley, J. (1983) The Wood Properties of Radiata Pine. Commonwealth Agricultural Bureaux, Slough, England.

Bartkowiak, M., Zakrzewski, R. (2004) Thermal degradation of lignins isolated from wood. J. Thermal Anal. Calorim. 77:295-304.

Bekhta, P., Niemz, P. (2003) Effect of high temperature on the change in color, dimensional stability and mechanical properties of spruce wood. Holzforschung 57:539-546.

Boonstra, M.J., Acker, J.V., Kegel, E., Stevens, M. (2007) Optimisation of a two-stage heat treatment process: durability aspects. Wood Sci. Technol. 41:31-57.

Boonstra, M.J., Tjeerdsma, B.K. (2006) Chemical analysis of heat treated softwoods. Holz Roh Werkst. 64:204-211.

Bowyer, J.L., Shmulsky, R., Haygreen, J.G. (2003). Forest Products and Wood Science - An Introduction. Iowa State Press, Iowa.

Brischke, C., Welzbacher, C.R., Brandt, K., Rapp, A.O. (2007) Quality control of thermally modified timber: interrelationship between heat treatment intensities and CIE $L * a * b *$ color data on homogenized wood samples. Holzforschung 61:19-22.
Bryne, L.E., Lausmaa, J., Ernstsson, M., Englund, F., Wålinder, M.E.P. (2010) Ageing of modified wood. Part 2: determination of surface composition of acetylated, furfurylated, and thermally modified wood by XPS and ToF-SIMS. Holzforschung 64: 305-313.

Callahan, D., Chittenden, C. (2009) Laboratory pure culture testing of treated radiata pine: a report prepared for Department of Chemical and Process Engineering, University of Canterbury. Scion, Rotorua, New Zealand.

Chemwatch (2007) Chemwatch Material Safety Data Sheet 10701: Linseed Oil.

Dickson, R.L., Walker, J.C.F. (1997) Selecting wood quality characteristics for pines. In: Proceedings of the CTIA/IUFRO International Wood Quality Workshop, on Timber Management Toward Wood Quality and End-product Value. Quebec City, Canada, August 18-22, pp. 45-50.

Esteves, B., Graça, J., Pereira, H. (2008a) Extractive composition and summative chemical analysis of thermally treated eucalypt wood. Holzforschung 62:344-351.

Esteves, B., Velez Marques, A., Domingos, I., Pereira, H. (2008b) Heat-induced colour changes of pine (Pinus pinaster) and eucalypt (Eucalyptus globulus) wood. Wood Sci. Technol. 42:369384.

Evans, P. (2003) Emerging technologies in wood protection. Forest Prod. J. 53:14-21.

FAO - Food and Agriculture Organization of the United Nations. Global Forest Resource Assesment: progress towards sustainable forest management. FAO, Rome, 2005.

Feist, W., Sell, J. (1987) Weathering behavior of dimensionally stabilized wood treated by heating under pressure of nitrogen gas. Wood Fiber Sci. 19:183-195.

Fengel, D., Wegener, G. (1984) Wood - Chemistry, Ultrastructure, Reactions. De Gruyter, Berlin.

Garcia, R.A., Cloutier, A., Riedl, B. (2006) Dimensional stability of MDF panels produced from heat-treated fibres. Holzforschung 60:278-284.

González-Peña, M.M., Hale, M.D.C. (2009a) Colour in thermally modified wood of beech, Norway spruce and Scots pine. Part 1: colour evolution and colour changes. Holzforschung 63:385393.

González-Peña, M.M., Hale, M.D.C. (2009b) Colour in thermally modified wood of beech, Norway spruce and Scots pine. Part 2: property predictions from colour changes. Holzforschung 63:394-401.

Gunstone, F.D. (2002) Vegetable Oils in Food Technology: Composition, Properties, and Uses. Blackwell-CRC Press, Osney Mead, Oxford.

Hakkou, M., Pétrissans, M., El Bakali, I., Gérardin, P., Zoulalian, A. (2005) Wettability changes and mass loss during heat treatment of wood. Holzforschung 59:35-37.

Hill, C.A.S. (2006) Wood Modification: Chemical, Thermal and Other Processes. John Wiley \& Sons, Chichester.

Hillis, W. E. (1984) High temperature and chemical effects on wood stability. Wood Sci. Technol. 18:281-293.

Johansson, D., Morén, T. (2006) The potential of colour measurement for strength prediction of thermally treated wood. Holz Roh Werkst. 64:104-110.

Kamdem, D.P., Pizzi, A., Jermannaud, A. (2002) Durability of heattreated wood. Holz Roh Werkst. 60:1-6.

Kim, D.Y., Nishiyama, Y., Wada, M., Kuga, S., Okano, T. (2001) Thermal decomposition of cellulose crystallites in wood. Holzforschung 55:521-524. 
Kollmann, F., Fengel, D. (1965) Änderungen der chemischen Zusammensetzung von Holz durch thermische Behandlung (Changes in the chemical composition of wood by thermal treatment). Holz Roh Werkst. 23:461-468.

Lungo, A.D., Ball, J., Carle, J. (2006) Global planted forest thematic study. Food and Agriculture Organisation of the United Nations (FAO), Rome.

Mabery, C.F. (1923) The heat treatment of China wood in linseed oils. Indus. Eng. Chem. 15:365-367.

Maclaren, P. (2002) Wood quality of radiata pine on farm sites - a review of the issues. Forest Farm Forest Manage Coop. Report No. 80.

MAF (New Zealand Ministry of Agriculture and Forestry) (2010) New Zealand wood availability forecast 2010-2040. MAF, Wellington.

Manalo, R.D., Acda, M.N. (2009) Effects of hot oil treatments on physical and mechanical properties of three species of Philipine bamboo. J. Tropical Forest Sci. 21:19-24.

Matsuo, M., Yokoyama, M., Umemura, K., Sugiyama, J., Kawai, S., Gril, J., Kubodera, S., Mitsutani, T., Ozaki, H., Sakamoto, M., Imamura, M. (2011) Aging of wood: analysis of color changes during natural aging and heat treatment. Holzforschung 65:361-368.

Mayes, D., Oksanen, O. (2002) Thermowood Handbook. Finnforest, Finland.

Mazella, B., Zakerzewski, R., Grzeskowiak, W., Cofta, G., Bartkowiak, M. (2004) Resistance of thermally modified wood to basidiomycetes. Wood Technol. 7: EJPAU.

Olsson, T., Megnis, M., Varna, J., Lindberg, H. (2001) Measurement of the uptake of linseed oil in pine by the use of an X-ray microdensitometry technique. J. Wood Sci. 47:275-281.

Pandey, K.K. (1999) A study of chemical structure of soft and hardwood and wood polymers by FTIR spectroscopy. J. Appl. Polym. Sci. 71:1969-1975.

Paul, W., Ohlmeyer, M., Leithoff, H. (2007) Thermal modification of OSB-strands by a one-step heat pre-treatment - influence of temperature on weight loss, hygroscopicity and improved fungal resistance. Holz Roh Werkst. 65:57-63.

Pétrissans, M., Gérardin, P., El Bakali, I., Serraj, M. (2003) Wettability of heat-treated wood. Holzforschung 57:301-307.

Phelps, J.E., Stokke, D.D., Pugel, A.D. (1994) Color analysis of white oak, edge-glued furniture panel stock. Forest Prod. J. 44:35.

Phuong, L.X., Takayama, M., Shida, S., Matsumoto, Y., Aoyagi, T. (2007) Determination of the accessible hydroxyl groups in heattreated Styrax tonkinensis (Pierre) Craib ex Hartwich wood by hydrogen-deuterium exchange and ${ }^{2} \mathrm{H}$ NMR spectroscopy. Holzforschung 61:488-491.

Powers, P.O. (1950) Mechanism of the heat bodying of linseed oil. J. Polym. Sci. 5:741-743.

Rapp, A.O., Brischke, C., Welzbacher, C.R. (2006) Interrelationship between the severity of heat treatments and sieve fractions after impact ball milling: a mechanical test for quality control of thermally modified wood. Holzforschung 60:64-70.

Repellin, V., Guyonnet, R. (2005) Evaluation of heat-treated wood swelling by differential scanning calorimetry in relation to chemical composition. Holzforschung 59:28-34.

Rosenqvist, M. (2000) The distribution of introduced acetyl groups and a linseed oil model substance in wood examined by microautoradiography and ESEM. International Research Group on Wood Preservation, Document No. IRG/WP 00-40169.

Rowell, R.M. (2005) Handbook of Wood Chemistry and Wood Composites. Taylor \& Francis Group, CRC Press, Boca RatonLondon-New York-Singapore.
Rowell, R.M., Banks, W.B. (1985) Water repellency and dimensional stability of wood. General Technical Report, FPL 50. Madison, WI: United States Department of Agriculture, Forest Service, Forest Products Laboratory.

Sailer, M., Rapp, A.O., Leithoff, H. (2000a) Improved resistance of Scots pine and spruce by application of an oil-heat treatment. The International Research Group on Wood Preservation IRG/ WP 00-40162.

Sailer, M., Rapp, A.O., Leithoff, H., Peek, R.D. (2000b) Vergütung von Holz durch Anwendung einer Öl-Hitzebehandlung (Upgrading of wood by application of an oil heat treatment). Holz Roh Werkst. 58:15-22.

Seborg, R.M., Tarkow, H., Stamm, A.J. (1953) Effect of heat on dimensional stabilization of wood. Japan Forest Prod. Res. Soc. 3:59-67.

Stahlhut, D., Farrell, R.L., Wakeling, R., Hedley, M. (2008) Wood decay fungi from New Zealand leaky buildings - PCR identification (Part 2) and aerial spore trapping. International Research Group on Wood Protection. Document no. IRG08-10649.

Stamm, A.J. (1964) Wood and cellulose science. Ronald Press Co., New York.

Stamm, A.J., Burr, H.K., Kline, A.A. (1946) Staybwood-heat-stabilized wood. Indus. Eng. Chem. 38:630-634.

St-Onge, V., Fortin, Y., Tremblay, C. (2005) Quality control of thermally modified balsam fir. In: Proceedings of Second European Conference on Wood Modification: "Wood Modification: Processes, Properties and Commercialisation', Göttingen, Germany, pp. 53-56.

Sundqvist, B. (2002) Color response of Scots pine (Pinus sylvestris), Norway spruce (Picea abies) and birch (Betula pubescens) subjected to heat treatment in capillary phase. Holz Roh Werkst. 60:106-114.

Sundqvist, B., Morén, T. (2002) The influence of wood polymers and extractives on wood colour induced by hydrothermal treatment. Holz Roh Werkst. 60:375-376.

Sutter, H.P. (1978) Method to determine the depth penetration of the biological active components of wood preservatives. International Research Group on Wood Protection. Document no. IRG/WP 2108.

Tappi Standards (1988) TAPPI-T222. Acid insluble lignin in wood and pulp.

Tappi Standards (1995) TAPPI-T 264. Preparation of wood for chemical analysis.

Theander, O., Bjurman, J., Boutelje, J.B. (1993) Increase in the content of low-molecular carbohydrates at lumber surfaces during drying and correlations with nitrogen content, yellowing and mould growth. Wood Sci. Technol. 27:381-389.

Tjeerdsma, B.F., Boonstra, M., Pizzi, A., Tekely, P., Militz, H. (1998a) Characterisation of thermally modified wood: molecular reasons for wood performance improvement. Holz Roh Werkst. 56:149-153.

Tjeerdsma, B.F., Boonstra, M., Tekely, P., Militz, H. (1998b) Thermal modification of non durable species. The International Research Group on Wood Preservation. Document No. IRG/WP 98-40124.

Tjeerdsma, B.F., Militz, H. (2005) Chemical changes in hydrothermal treated wood: FTIR analysis of combined hydrothermal and dry heat-treated wood. Holz Roh Werkst. 63:102-111.

Tjeerdsma, B.F., Swager, P., Horstman, B.J., Holleboom, B.W., Homan, W.J. (2005) Process development of treatment of wood with modified hot oil. In: Proceedings of Second European Conference on Wood Modification: "Wood Modification: Processes, Properties and Commercialisation', Göttingen, Germany, pp. 186-197. 
Tuong, V.M., Li, J. (2011) Changes caused by heat treatment in chemical composition and some physical properties of acacia hybrid sapwood. Holzforschung 65:67-72.

Walker, J.C.F. (2006) Pine in perspective. In: WTRC Workshop: "Strategies for Growing High Wood Quality Trees and Processing and Utilization of Wood Products". Ed. Pang, S. University of Canterbury, Christchurch, New Zealand, pp. 1-11.

Wang, E., Karalus, A., Sutherland, J., Pang, S. (2008) Stability properties and performance of Douglas-fir and radiata pine. In: WTRC Workshop: "Maximising Benefits of Forestry and Wood'. Ed. Pang, S. University of Canterbury, Christchurch, New Zealand, pp. 88-96.

Wang, J.Y., Cooper, P.A. (2005) Effect of oil type, temperature and time on moisture properties of hot oil-treated wood. Holz Roh Werkst. 63:417-422.

Welzbacher, C.R., Rapp, A.O. (2002) Comparison of thermally modified wood originating from four industrial scale processes - durability. The International Research Group on Wood Preservation IRG/WP 02-40229.
Wikberg, H., Liisa Maunu, S. (2004) Characterisation of thermally modified hard- and softwoods by 13C CPMAS NMR. Carbohydrate Polym. 58:461-466.

Windeisen, E., Strobel, C., Wegener, G. (2007) Chemical changes during the production of thermo-treated beech wood. Wood Sci. Technol. 41:523-536.

Wolkenhauer, A., Avramidis, G., Militz, H., Viöl, W. (2008) Plasma treatment of heat treated beech wood - investigation on surface free energy. Holzforschung 62:472-474.

Yildiz, S., Gezer, E.D., Yildiz, U.C. (2006) Mechanical and chemical behavior of spruce wood modified by heat. Build. Environ. 41:1762-1766.

Zaman, A., Alén, R., Kotilainen, R. (2000) Thermal behavior of Scots pine (Pinus sylvestris) and Silver birch (Betula pendula) at $200-230^{\circ} \mathrm{C}$. Wood Fiber Sci. 32:138-143.

Received September 2, 2010. Accepted June 6, 2011. 